\title{
Criminal Risk, Media Representation and Role of the Criminal Law Culture
}

\author{
Mario Caterini \\ University of Calabria, Rende, Italy \\ Email: mario.caterini@unical.it
}

Received 5 February 2015; accepted 7 March 2015; published 11 March 2015

Copyright (C) 2015 by author and Scientific Research Publishing Inc.

This work is licensed under the Creative Commons Attribution International License (CC BY). http://creativecommons.org/licenses/by/4.0/

(c) (i) Open Access

\begin{abstract}
First of all, the essay is about the media's redundant emphasis on risks and the elitist specious creation of collective worries, in particular with relation to the criminal phenomenon, presenting the results of criminological researches that validate the empirical demonstration of the media representation's artificiality of criminal risk. The second part of the essay is dedicated to the influence of the media representation on the legislative choices of criminal politics, in particular in the actual contexts of the so-called "liquid democracy" developed around the new media, focusing the attention on the risks that it might involve with reference to the violation of some fundamental principles in the democratic modern systems. The conclusion is dedicated to the criminal law culture in a possible process of criminal-political paideia adapted to democratic and mass media postmodern needs, trying to track the ontological content of the minimum levels of knowledge of the citizens, such as the internalization of those fundamental values that constitute the ethos of the contemporary civil society.
\end{abstract}

\section{Keywords}

Criminal Risk, Media Representation, Criminal Politics, Principle of Legality, Liquid Democracy, Role Criminal Law Culture

\section{Introduction}

In today's society-it has been affirmed authoritatively—security is only a social pretense and, as a consequence, the overcoming of risks is merely symbolic ${ }^{1}$. And as a matter of fact, the role of the mass media follows

${ }^{1}$ See Moccia, 2013: p. 410, according to which "Security, therefore, is not anymore the consequence of a social order that tends to justice, but it is the result of vague political choices, oriented in the best of cases to the "damage reduction"; in any case, as the experience of these years demonstrates, they are condemned to collapse, also because the person, his individuality, more or less anguishing, do not let substitute himself for mathematical sets or statistical clusters. In these terms, security is only a social fiction: so the overcoming of risk is destined to be only symbolic. The actuarial average of private emotions, casually confused with the public opinion, is often supported by a very inattentive, misinformed and, maybe, bad faith legislator”. 
this direction in an increasingly crucial way, especially through the Internet today, which is able to progressively influence the perception of such phenomenon ${ }^{2}$. These considerations are also valid for the risks related to the criminal happenings and the associated pretension of security ${ }^{3}$. To this end, the risk has a socio-cultural derivation, whether in its objective construction or in its subjective perception ${ }^{4}$. In these cases, the criminal risk frequently appears as socially produced through the creation of fake "enemies"

\section{The Media's Redundant Emphasis on Risks and the Elitist Specious Creation of Collective Worries}

The perception of the risk doesn't follow a linear way (that is, starting from the happenings, passing through the mass media, to finish with the partners), but through a circular process of sources that reciprocally stoke one another ${ }^{6}$. Through the use of the collective experience and also the horse sense, in fact, the communications media perceive and intercept the supposed risks that attract the partners and, through the factitious typical of the media representation, they are able to influence and emphasize such a collective perception. This perception, then, is strengthened further by the same media that gain it one more time from that horse sense, according to an increasing amplification mechanism, comparable to such an autopoiesis reproduction that is a faulty, swirling spiral not always containable ${ }^{7}$.

From this vicious circle, furthermore, often a "security question" arises, coming from the media and the so-called public opinion conditioned by the media, to which frequently corresponds the so-called "public response" that, with relation to the criminal phenomenon, has a political nature, which is the emanation of new rules [frequently symbolic to face the perceived risk; or it has a judicial nature, that is to say the initiatives of the magistracy that increasingly result in the so-called "lively jurisprudence", in which there is a "stretching" of the letter of the rules to satisfy the supposed needs of security coming from the public opinion ${ }^{8}$. The vicious circle can continue with the socio-political effects caused by the so-called "public response", effects that in turn attract other media reactions that in turn give rise to another social perception, which consequently often require a new "public response". Therefore, the perception of the risk is founded on a system of mutual urges and interferences that, when all is said and done, culminates in a clash to impose such an interpretation of the reality ${ }^{9}$.

In this chasing and endless [short] circuit, the task to select the news represents the main power of the mass media, including on the web ${ }^{10}$. To ascertain that a precautionary evaluation of the news susceptible of diffusion must occur, the matter is based especially on criterion chosen for that ${ }^{11}$. The communication media makes a discrimination between what is considered information against what is not, in the sense that it does not cause inter-

\footnotetext{
${ }^{2}$ In general about the influence of the communication media in the social perception of reality, see Eco (2012); in particular about the influence by means of new media see Meyrowitz (2002).

${ }^{3}$ The right to security has been object of many authoritative researches in the field of criminal law studies; within them, recently, see Pulitanò,2009: p. 547; Donini, 2008: p. 3558; Hassemer, 2008: p. 15; Baratta, 2000: p. 19; at last, Cavaliere, 2009: p. 111.

${ }^{4}$ About the perception of risks see Savadori \& Ruminati, 2005: p. 44; Slovic (2000), passim. About the so-called "risk society" and the deep alteration of the structure of the criminal justice system in contradiction with its fundamental principles, see Stella (2001), passim, spec. p. 387, p 415. For a risk analysis by the criminal law point of view, endo and esosystemic, more recently see Perini (2010), passim, spec. p. 4, p. 168.

${ }^{5}$ About the media's emphasis on risks see, within others, Vianello \& Padovan, 1999: p. 247. About the influence of the communication media in the social perception of the "enemy", see Dino, 2006: p. 824. In general, about the social construction of the risk see Beck, 2000: p. 35 ss., spec. p. 337; Amendola, 1995: p. 20.

${ }^{6}$ Priulla, 2005: p. 63.

${ }^{7}$ With reference to the criminal phenomenon and the capacity of media to supply deformed interpretation models, see Erickson (1991), p. 219 ss., according to which the information media are not able to create opinions o convictions, but stimulate and develop the inclinations of citizens, according to a relational model in which the media offer an interpretation of reality that coincide with the citizens point of view.

${ }^{8}$ It is very plausible, in fact, that the media system might also influence the magistrates into the phase of taking some decision, orienting not only the inspection of the event but also the interpretation of the norms, toward a result instead of another, according to the expectations of the so-called public opinion. Romano, 1985: p. 413, as well as a social consensus that can be referred to the creation of the norms, it is also about a social consensus "with reference to the dialog-communicative structure of the process [...] which last result- the decision to condemn or acquit-conditions the social comprehension of the judicial activity and it is probably conditioned in turn”. Many researches, especially into the common law systems have verified empirically the mass media influence on the decision process of the professional judges and also jury members especially about the proof of fact; see Costantini \& King, 1981: p. 36; Studebaker \& Penrod, 1997: p. 428; Tyler, 2006: p. 1050; in Italy, for the psycological profiles, see the report of the meeting "Magistrates and Mass Media”, organized by CSM, Rome, 2004, in particular Arcuri, 2004; Rumiati, 2004.

${ }^{9}$ Ericson, Baranek, \& Chan, 1989.

${ }^{10}$ About the topic see Marini, 2011; also see Bentivegna (2002), in particular the first part with the writings of McCombs \& Shaw (2002), Benton \& Frazier (2002) and Iyengar \& Kinder (2002).

${ }^{11}$ It has been asserted that the strongest influence of the mass media on politics and voters does not happen through a sort of imposition and ideological contents, but for the selective processes of the information inspired to internal logics of the media system; cfr. Caniglia, 2000: p. 180.
} 
est for the audience ${ }^{12}$. Within the free economies, in fact, the popular logic is to divulge only the news that is more commercial, more desirable and that which, more so than others is able to stimulate the emotions, just like some criminal events ${ }^{13}$. This usually happens to the detriment of the information on phenomenon without any media appeal, which would be more relevant, for example, in a serious political-criminal discussion. The "commercial" selection of the news susceptible of diffusion and, therefore, the subjects of public debate, is also able to produce an unbalanced distribution of resources concerning the political, legislative and financial choices, which if conditioned by populist pushes, will not be very sensitive to the more real and serious risks, but those more manifest instead ${ }^{14}$.

The media's redundant emphasis on the more "marketable" risks, can lead to instinctive social alarms; a sort of collective anxiety that frequently does not have a real defense; it is only the so-called paradox of fear in which the emotion intensifies the reality ${ }^{15}$. The theorization of the fear as an instrument of social control has remote and very authoritative origins ${ }^{16}$. Today, however, the mass media and particularly internet, in which the emotionality arrives to the parameter of choices, can supply extraordinary instruments of persuasion through the fear, more and more central in the politic world, to such an extent that phenomenon-producing social fear, emphasized, frequently conditions the legislative initiatives of [symbolic] contrast of the same phenomenon, intended to attract the approval of voters ${ }^{17}$. At this point is very clear that fear can be catalyzed, manipulated, exploited, to such an extent that it can be totally created and, when it happens, the supporters are the political, economic and media elites ${ }^{18}$. The role of mass communication-in which the internet is going to have a growing influence—-becomes indispensable to create fear spreading through the perception of the risks ${ }^{19}$.

\section{The Empirical Demonstration of the Media Representation's Artificiality of Criminal Risk}

In order to confirm what has been outlined until now, in particular referring to the risks and the alarms connected to criminal events, it is useful to gain the empirical-criminal research to understand which events susceptible of criminal significance are popularized through the media, and how ${ }^{20}$. The inclination is to intensify the risk perceived by the community in relation to the criminal events, especially several criminal typologies, represented by mass media as a much more widespread phenomenon than it is in reality, expanding its consistence compared to that which can be officially found in the verified statistical data ${ }^{21}$.

\footnotetext{
${ }^{12}$ Just as the law is conformed to the licit/illicit, the communication media are conformed to the different code: information/not information; cfr. Luhmann, 1990: p. 62; Luhmann, 1995: p. 17.

${ }^{13}$ Garland, 2004: p. 174.

${ }^{14}$ Priulla, 2005: p. 67. For the debate about the so-called penal populism, recently see Fiandaca, 2013: p. 95; Pulitanò, 2013: p. 123.

${ }^{15}$ The literature about the fear of crime is very vast; see Simon (2008), passim; Cornelli (2008), passim; Merzagora Betsos \& Travaini, 2003: p. 51; Travaini (2002), passim, spec. p. 19; for a recent attempt to overcome fear through security policies oriented toward the democracy, see Ceretti \& Cornelli (2013).

${ }^{16}$ For the political usage of fear in the thinking of Hobbes, Montesquieu and Tocqueville, see Robin (2005), p. 41, p. 81, p. 91.

${ }^{17}$ In this sense the words of Zaffaroni, 1989: p. 139 are particularly important, according to what he says "The mass media-and especially the television - are indispensable elements to exercise the power of the whole penal system. If they didn’t exist [...] it would be impossible to provoke fear [...] the communication media are the creators of the illusion related to the penal systems [...] they deal with the early introjection of the penal model as a pretended solution model of the conflicts [...] which are in charge of creating the illusion of the system efficiency”.

${ }^{18}$ Chomsky \& Herman (1998), trad. it. S. Rini (2014), passim, have proved the elitist mechanism through which the world of information activates the public opinion to sustain and defend the particular interests that control the society: "The main social goal of the media is to instill and defend the economic, social and political projects of the privileged groups that control the society and the State. The media are at the service of this goal in many ways: selecting themes, distributing them according to a level of priority and importance, contextualizing the questions, screening the information, choosing emphasis and tone, and maintaining the debate within the limits of the acceptable premises" (p. 363). Robin, 2005: p. 199, affirmed that "The elites [...] as official protectors of the community security, decide which threats are more relevant [...], define the nature of the threat, from where it comes and how it must be fought, deploying the citizens against it”. In the political-criminal perpective there is the campaign of law \& order to recover or reinforce the consensus; cfr. Paliero, 2006: p. 523; in general about the role of the consensus of criminal law, Paliero, 1992: p. 849.

${ }^{19}$ If then the political power is able to control the mass media-through new impositions or property concentrations-, the alteration of the democratic system is further as the political forces might be able to stimulate the public opinion and the reforms they desire; see Palazzo, 2009: pp. 202-203; Giostra, 2007: p. 66.

${ }^{20}$ In general see Forti \& Bertolino (2005), passim; more recently also see Bianchetti (2012), passim, spec. p. 154 ss.; less recently Grandi, Pavarini, \& Simondi (1985), passim.

${ }^{21}$ Forti \& Redaell (2005), passim, spec. p. 12 ss., p. 18 ss., p. 179; Gebotys, Roberts, \& DasGupta, 1988: p. 3. For more numeric imbalances and significant super-representations (due to omission), in particular criminal reports relating to citizens and foreigners, see Calvanese 2011: p. 115. About this topic see also Paliero, 2006: p. 493. For the analysis of the considerable growth of criminal news into the English press, see Robert, Livingstone, \& Allen, 2001: p. 174. For some synthetic problematic observations about the difference between "effective” and "perceived" criminality, see Padovani, 2008: p. 690, who highlights that the presumed misinformation operated by the media, should be compared with the possible statistics ignorance of the criminal phenomenon to test the effective consistency; with eventual different territorial relocations and gravity of criminal events, and with the "unclear number" of crimes not reported.
} 
The majority of the news concerning criminal events is rejected in favor of execrable events presented with a strong charge of disvalue. The agenda setting related to the criminal typologies is tight and restrictive, with news concerning various traditional, violent crimes (e.g. murder, terrorism, etc.) almost exclusively reaching the audience, while other events do not grasp any media attention or rather it is very limited, with the exception of some types of events (e.g. sexual crimes or against childhood) that, even if they are ignored generally, usually appear in the limelight of news stories referring to specific events emphasized for seriousness. Furthermore, often the crimes that are statistically more frequent, such as those against property, if in some cases (especially in newspapers) they appear frequently in relation to the number of news, they also lack total media divulgation, whether in column space or time dedicated to them ${ }^{22}$. Mass media, moreover, tends to overestimate the seriousness of some crimes compared to the "official" non-value assigned to the system through the "edictal provisions" ${ }^{\prime 23}$.

So mass communication tends to mainly publish the rarer criminal events, although considered serious and emotionally exciting, and unquestionably less in the case of the most common crimes, considered less relevant because they do not capture interest in the community. Mass communication, therefore, is apt to invert the order of the real statistics, neglecting crime as a wide social phenomenon and instead focusing on single events able to attract audience and profit ${ }^{24}$. The empirical data emerging from the criminological research validates the artificiality of the criminal risk perception as it appears in the media system, and also explains-according to the mechanisms that will be explained better later-many populist and "omnivorous" political-criminal choices, that in the last decades have contributed to the formation of the so-called emergency criminal legislation ${ }^{25}$. In fact, if irrational social instances of criminal repression are created in the media, politics tend to prepare criminal answers that are usually symbolic, aimed at social reassurance and also to gain approval, but ineffective, useless, unsuitable and oriented towards the affiliated nonetheless ${ }^{26}$.

\section{The Influence of the Media Representation on Criminal Politics Choices}

The artificiality of the media representation of the criminal risk, empirically demonstrated as such by crime investigations, is also useful to evaluate how legislative choices are made, increasingly conditioned by the actual methods carried out in politics, especially after the decline of the clearest ideological conflicts in history ${ }^{27}$. In fact, as the so-called "affiliation vote" is weakened, the political forces must distinguish themselves from others in order to attract a not entirely ideological consensus. So, the systems which intend to gain the favor of voters - on the model of the so-called "take-all party" - are based especially on the electoral "market" analysis, increasingly oriented toward techniques comparable to marketing ${ }^{28}$. The archetype is borrowed from a typically commercial rationality, in the sense that the political organizations are equalized to the companies, and exactly like them, they succeed more with reaching their objectives, putting the consumer needs at the beginning and not at the end of the production process, just as the political parties, in order to attract consensus, need to base the creation of their programs primarily on the needs of voters. For this reason, the political project of a party, ac-

\footnotetext{
${ }^{22}$ Forti \& Redaelli, 2005: p. 92. About the selection of distorting crime news, see also Surette (2007), passim. The tendency is present also in other experiences, for example the Irish one, see O’Connell, 1999: p. 191, who analyzed more than 2000 articles and the distortions operated by the media, connected to the inclination to popularize serious crime news even if they are frequent. For the Scottish experience, see Ditton \& Duffy, 1983: p. 159. For the Austrian one, Gunz, 1980: p. 3; for the German one, Kury, 2005: p. 319.

${ }^{23}$ Cfr. Forti \& Redaelli, 2005: pp. 140, 158.

24About the inversion of the real statistical order, see Forti \& Redaelli, 2005: pp. 140, 182, that, during the comparison of the media presence data of the crime typologies with the numbers expressed into the criminal law statistics have taken into account the Istat data related to year 2000. See, furthermore, Paliero, 2006: p. 494. See also, Surette, 2007: p. 63; Schneider, 1995: p. 148.

${ }^{25}$ In general, about the problems connected to the emergency legislation, see the fundamental and by now classical work of Moccia (1997), passim. More recently, again, Moccia, 2013: p. 414, it is about a "globalizing, 'omnivorous' criminal law" that shows the crisis that the criminal, formal and content legality experiences currently. "The penal laws by now are, too often, became simply 'written rules', with a casual content: but they are connected, or maybe probably, to a strict punishment, without the emersion of a legitimateness of the sanctionatory treatment by the content of the prohibition". About Donini, 2004: p. 55, in the last decades, in Italy, the "criminal law of the enemy" has been called "criminal law of emergency".

${ }^{26}$ See Donini, 2006: p. 735, that in the matter of the impossibility of controlling the distorting use of mass media, talks about press and/or political invention of "monsters" as exploitation of the person that creates the second significance of the term "enemy", that is to say the exploitable use of the criminal law as a function of "fight" against "evil" committed by a normal kind of author. More recently Schiaffo, 2012: p. 52, in particular about the "announced disaster" of privatization in the management of public security of the Italian legislation during the years of the media sudden growth of criminality.

${ }^{27}$ About the influence of mass media on the political agenda, in particular, with reference to the media indication of the criminal phenomenon as a permanent question of the same agenda, see Fuentes Osorio, 2005: pp. 16, 23

${ }^{28}$ The theory of the "take-all” parties comes from Kirchheimer, 1966: p. 177, ora in G. Sivini (1971), p. 177, in particular p. 192.
} 
cording to this model, should not be an ideological standard product, but the result of research conducted on the electoral "market".

Political marketing seems to have been inspired by a higher sense of democracy, simply because the legislator could not dictate his ideology, but was limited to gathering the preferences of the citizens ${ }^{29}$. The validity of this conclusion is subordinated to correctness, directness and democracy of the processes that give birth to and develop ideas, expectations and anxiety of the citizens. It can be affirmed that the democratic nature of such model for the most part is tied to the objectivity and democracy of the mass communication ${ }^{30}$.

Indeed, the fact that the media system is able to influence the political agenda implies that the same political options will be subjected to the philosophy subtended to the functioning of the mass communication ${ }^{31}$. If these logics are guided mainly by economic interests, profit and also the models and the ideas instilled into the political programs and the criminal legislation, they will be shaped indirectly to less democratic and more economic reasons ${ }^{32}$.

The methodology of marketing, in order to adapt to the mass communication, is also established on a maximum simplification of themes and debates. The complexity of the questions and the relative argumentations is removed to leave space for a slogan, brief and easy to understand assertions, able to obtain the approval of vot$\mathrm{ers}^{33}$. Furthermore, in this case it can be that the marketing strategies are more democratic because-following an inclusive philosophy - they mark a political communication in line with the common language of the citizens $^{34}$. In this case, however, the value of this conclusion must be verified by analyzing the risks connected to a deleterious simplicity, inadequate to tackle complex questions, such as the criminal politics destined to infringe on the fundamental freedoms of humankind. In this perspective, therefore, the political marketing does not seem to be a more democratic strategy in itself, because-almost as if the problematic nature was incompatible with democracy - it pushes toward a banality of the questions, toward suffocating themes, simply because they are popular, easily understandable and subject to voter anxiety conditioned by the media ${ }^{35}$. A mature model of democracy, instead, cannot tolerate the media shutdown and the political oblivion of more serious and complex questions and argumentations ${ }^{36}$.

The symbolism that has characterized the criminal politics of the last decades, therefore, seems to be a consequence of the bigger concept of "symbolic government" in which the objective of the power has become the management of the same power ${ }^{37}$, that is, moreover, a consequence of the difficulty of mass circulation of the most imposing and serious ideas inspired by the fundamental values of a social state of law.

To summarize, if, on the one hand, the system's democracy is not safeguarded per se by the political marketing, on the other, the same marketing nonetheless is orienting the so-called "public response"-also the criminal legislation-more and more toward the "commercial" and simple trends coming from the media system ${ }^{38}$. The worries that generally derive from the effect of the marketing on politics ${ }^{39}$, that is from the commercialization and trivialization of ideas, are even more serious, with particular reference to the criminal politics that affect the fundamental human rights, such as freedom and dignity ${ }^{40}$. "Marketing" the ideas of criminal politics, in conclusion, may be equivalent to simplifying, exploiting, commercializing and "selling" the most personal characteris-

\footnotetext{
${ }^{29}$ Harrop, 1990: p. 277; Scammell, 1995: p. 298; Cattaneo \& Zanetto, 2001: p. 13.

${ }^{30}$ For ${ }^{\text {some }}$ critics to the political marketing inspired to the democratic models, see Franklin (2004); Jamieson (1991).

${ }^{31}$ According to Qualter, 1985: p. 138, marketing reduces politics to marketable images.

${ }^{32}$ In the Italian literature, for the relation between democracy and political marketing, see Mori, 2011: p. 563; Mori, 2012: p. 711. Palazzo, 2009: p. 203, in the matter of law of markets that strongly regulate the representation of the criminal phenomenon, he speaks about "a methodologically anti-democratic drift".

${ }^{33}$ They are informative shortcuts “that function as ‘second choice’ of other kinds of data” cfr. Popkin \& Dimock, 1996: p. 182.

${ }^{34}$ Harrop, 1990; Scammell, 1995.

${ }^{35}$ About the strong uncertainties related to the excessive simplification of the political and information language, with obvious consequences on the honesty of the electoral choices, see Caniglia, 2000: p. 191.

${ }^{36}$ Smith \& Saunders, 1990, p. 295.

${ }^{37}$ Cfr. O’Shaughnessy, 2004: p. 232.

${ }^{38}$ If the social science doesn't agree on the nature and the power of mass media, as it is not easy to distinguish their influence compared to the influence of the education, religion, etc., everyone agrees on the power they have on the political agenda; cfr. Butler \& Collins, 2004: p. 98. For the intimate implications between political marketing and mass media, distinguished between free and paid media, see Scammel, 2004: p. 39; Wring, 2004: p. 121; O’Shaughnessy, 2004: p. 228.

${ }^{39}$ Constriction of the public agenda, caution of the media messages rather than arguments, depletion of the political "bravery”, etc. Cfr. Scammel, 2004: p. 57; Butler \& Collins, 2004: p. 85.

${ }^{40}$ For some consideration about the alteration of the democratic circuit coming from the distorted media representation, in particular the trial cases, see G. Giostra (2007), p. 66. About the spectacularization of the trial, see Canestrari, 1995: p. 52.
} 
tics of human kind ${ }^{41}$.

\section{5. "Liquid Democracy" through the Internet: The Dangers for Legitimate Criminal Politics}

The communication based on new technologies is facilitating the hopes of overcoming the so-called representative democracy in favor of the direct one ${ }^{42}$. "Liquid democracy" means a system in which, through free software, every citizen has the power to choose and exercise their political rights that consist of express proposals and vote them, or empower them, even if always in a revocable way, in order to render useless a unitary and periodic mechanism of election of spokespeople ${ }^{43}$.

For this reason, the new media are supporting the conviction that the best ruler should be the public opinion. Through its dialogue structure, the Internet would permit a counter-revolution able to change the democratic mechanism, permitting the overcoming of the representative crisis of politics through the power bestowed upon every citizen to frequently demonstrate their preferences through a sort of permanent referendum method ${ }^{44}$. This topic is very current, especially after the assertions, as well as the criminal politics initiatives, of organizations that have founded on the Internet their philosophy intended to obtain a direct participation of the voters for the decisions, eliminating the mediation of the elected ${ }^{45}$.

The idea would be to virtually create a new Ancient Agora of Athens through interactive technologies, able to keep citizens increasingly well-informed and able to guide public choices without any mediation of professional politicians.

Unlike the traditional media, the dialogue feature of the Internet-that is to say its bidirectional nature that permits the exchange of information-is considered the main requirement of its strong democratic vocation. This technological characteristic, in fact, is a great innovation compared with the press, radio or television which do not permit the users to "converse" directly. This fundamental quality of the Internet in itself, after all, does not seem to guarantee the democracy of a political system, and a contrary conclusion probably reveals itself as a myth. In fact, new technologies, on the one hand, can also be used for a distorted use, such as, for example, the legitimization of authoritative wills through the ratification of despotic decisions; on the other hand, the Internet alone cannot completely substitute the traditional democratic processes representative of the social-political conflict, but if anything, it can enrich them by establishing, with duly guarantees, valid help able to improve the level of democracy of a system ${ }^{46}$.

On the one hand, the problems posed by the new media, are analogue to those of traditional mass communication, connected to the logic of the economic advantage and old or new lobbies that are able to condition the strategies $^{47}$. On the other hand, they present additional problems coming from the enormity and the usual low quality of information published on the web, which also precisely due to the exorbitant quantity and the popular chaos stemming from it, with great difficulty, in fact, can instill in the citizen a better knowledge of the so-

\footnotetext{
${ }^{41}$ See S. Moccia (2013), p. 411, according to which "L'orientamento attuale ai flussi emotivi dei consociati o di lobbies, anche per demagogiche finalità elettorali, spinge il legislatore_ — o chi per esso_—ad esaudire i desideri di criminalizzazione, al di là di parametri di effettiva meritevolezza di pena di talune condotte”.

${ }^{42}$ About this topic, see De Rosa (2014), passim; Putini, 2013: p. 42.

${ }^{43}$ For a more complete definition of "liquid democracy" see Bernabè, Marcolini, \& Rostello, 2013: p. 13. The authors might permit the practice of the delegate voting in connection with free computer programs, for example currently the most famous: "Liquid Feedback", that is a platform used by the so-called Pirate party. About "liquid democracy” and the Pirate party, see De Rosa, 2014: p. 105.

${ }^{44}$ Shapiro (1999), passim.

${ }^{45}$ The reference is related to the electoral affirmation obtained by the Movimento 5 Stelle in Italy. About it, recently, see Floridia \& Vignati (2013). According to the authors, in the ideas of the Movimento mix three different challenges to the representative democracy, causing more than a contradiction: reformatory (through instruments of direct democracy, such as referendums and petitions, in a context that preserve the centrality of the Parliament), utopic (overcoming of the representative democracy through computer instruments); and a plebiscitary challenge (through web and squares) See also Bernabè, Marcolini, \& Rostello, 2013: p. 17 ss., according to which “"Movimento 5 Stelle” is the continuation of the old but in new forms”. Also see Fornaro, 2012: p. 253. The members of the parliament belonging to the M5S presented numerous political-criminal bills: political exchange between politics and mafia, prevention and conflict of the corruption, auto-money laundering and possession of financial activity abroad, company, taxation and bankruptcy crimes, prohibition to carry out the electoral propaganda at the expense of people belonging to mafia associations and exposed to prevention measure of special surveillance of public security. The so-called "democratic emergency", after all, and the rising protest that demands new forms of direct democracy, also concern the rest of Europe and Occident, as proved by the communicative success of movements such as the Indignados, Occupy and the so-called Pirate party.

${ }^{46}$ The topic about the relation between democracy and new communicative technologies is object of a vast literature. See: Rodotà, 1997; Lévy (2002); Lévy (2008); de Kerckhove \& Tursi, 2006; Pittèri, 2007. More recently Corchia, 2011.

${ }^{47}$ Lombardini, 2001: p. 62; Longo, 2001: p. 70, that is about a network strongly identified with the market, of which the anti-democratic dimension of money is exalted.
} 
cial-political questions ${ }^{48}$.

The revolution presented by the interactive "liquid democracy", once again seems to be mainly symbolic. At least at the moment, in fact, the opinion as a slogan, according to which the problems of democracy could also be immediately solved through the Internet, cannot be shared. For many reasons: first of all, not everyone can use the new technologies and even those who do use them, often cannot use them effectively; those who are familiar with it are a minority. Furthermore, today the prevalence of web contents is managed by a small group of "transmitters", but using the same market logics, therefore with the famous antidemocratic implications. In the end, the information chaos deriving from the vastness of the content published, in essence corresponds to misinformation ${ }^{49}$.

Recently, also among the promoters of internet as an indispensable instrument to improve the democracy of a system, new critics in the form of the so-called "liquid democracy" have emerged, due to the inappropriateness to give citizens the possibility to directly vote for law proposals, because it would require great knowledge that citizens do not have. Therefore, a different model of democracy has been proposed, known as "enunciating", nevertheless based on the usage of new technological media. This idea, even if it continues to consider the necessary parliamentary institutions, implies the abandonment of the classic representative democracy (that is the obligation of the mandate), but in favor of a system in which the elected representatives only have the task of expressing in the laws the will of the representatives. The elected, considered as a sort of simple nuncius, for this reason should be a perfect representative, able to express the will of the majority of his voters every time. This, after all, presupposes the possibility of the representative knowing perfectly this will, provision that could be carried out nowadays through new technologies, particularly through an IT platform able to guarantee the whole participation of the community in the political choices and, more specifically, a direct relation and control between the representative and the voter ${ }^{50}$.

This model abandons the utopic idea of "liquid democracy" founded on the direct power of citizens to create laws, to move themselves toward an obligation that is the parliamentary mandate in which the voters should have the power, to practice through information technology, to impose on their representatives the "preliminary objectives" to follow, as well as to stimulate and control the realization of these objectives. Apart from the classic terms on the Rousseauian idea of the imperative mandate ${ }^{51}$, the model of the "enunciating democracy", although constitutes an interesting democratic effort of internet, does not seem to overcome the questions mentioned before, relating to the preconditions of "how" the citizens will mold the ideas around the "preliminary objectives" to follow ${ }^{52}$. If this happens, even if in the way described before, through the mass media filters able to commercialize, trivialize and falsify the messages, therefore-remaining in the field of criminal politics — the unique shelter against the possible demagogic, repressive, emotive and irrational pushes, remains a "knowledgeable" "non-commercialized" legislator without any obligation of mandate.

Today, after all, it is not possible to ignore the pushes toward a democratic use of the Internet and a phobic attitude toward the new technologies would constitute the outmoded sign of reactionary short-sighted politics. Instead, we need to recognize the democratic potential of new media, not as the miracle cure for all the democratic deficiencies, but as a useful instrument, with the proper guarantees, to assign popular sovereignty to the citizens. However, it does not obstruct the awareness that the cornerstone of democracy exists not only and not so much in the moment of voting, but primarily in the participation in the discussion that requires correct information about socio-political questions. Well then, starting from this prerequisite, the problems of democracy are the same for the traditional communication media and also for those that use new interactive technologies. In both

\footnotetext{
${ }^{48}$ Eco (2012), in the chapter Veline e silenzio claims: "The Internet, naturally, represents, without any intention to censor, the maximum noise through which it is impossible to receive any information. In other words: first, if an information is received, it is hard to know if it is reliable; second, try to search an information on the Internet: only we, scholars, spending ten minutes on it, start to screen and find the information we need. All the other users are fixated on a blog, on a specific porn, e.g., but at the end they don't surf the web so much, because surfing doesn't permit to collect a reliable information”. Also see Lombardini, 2001: p. 64.

${ }^{49}$ Davis (1999), passim; Mazzoleni, 2001: p. 80.

${ }^{50}$ The model is proposed by Bernabè, Marcolini, \& Rostello (2013), passim.

${ }^{51}$ The topics in favor of the idea that gives to the representative a consistent space of autonomy, in fact, traditionally are founded on reasons of principle and technical nature. About the first ones, the freedom of mandate is considered connected to the idea of "common good" whereby all those instruments able to favor particular interests into the public field must be rejected. On the technical point of view, instead, the obligation of mandate would find an obstacle into the institution of Parliament, as it would be a mechanism able to limit or block the operation. About the topic in general, see Girelli (2007), passim; Scarciglia (2005), passim. About the theoretical reasons of the imperative mandate ban, less recently, see the important, even if short work written by Burke, 1983: p. 66; and also Zanon, 1991, passim., spec. p. 87.

${ }^{52}$ About the civil liberties as a precondition of the practice of participation rights, see Pace, 2003: p. 21.
} 
cases, the difficulty to overcome is first and foremost always the same: the correct and balanced training and information of citizens, which after all, in relation to the Internet, sometimes seems delicate whether for the lack of rules of guarantee or for the informative chaos which derives from them.

The principle of criminal law and democratic legitimateness of the legislator should tend to guarantee representativeness, rationality and extreme prudence in the recourse of the punitive sanction ${ }^{53}$. If these features of the penal system have been threatened for decades by the so-called legislation of emergency, they should be threatened even more by the hasty usage of the Internet. In fact, a politic use of the dialogue capacity of the Internet (such as, for example, the instantaneous referendum, or the political marketing polls, or the "vote" of proposal to transfer into the Parliament), if not accompanied by a mass of guarantees of real democracy of the media tools, seems modestly compatible with a penal system truly shaped on a extrema ratio ${ }^{54}$. The economic interests buried in the web, the information technology chaos of the web, the scarceness of those who have adequate information technology knowledge, will probably direct the citizens toward emotive, little representative, irrational and repressive reactions. Reactions that, pursuant to the political marketing processes described, can concretely influence several criminal-political choices ${ }^{55}$.

The interactivity, therefore, if not accompanied by some guarantees, might stoke plebiscitary swerves, according to a grotesque model of direct democracy, in which the reasoning and the public control are annulled, in favor of an illusionary decisional capacity founded on the oppression of an inexistent majority or exploited by the media ${ }^{56}$. The media system in its entirety, a fortiori considering the further dangers coming from the internet, seems to install the basis of the criminal constitutional law, under more than one profile: a single apparent democracy of the media choices that influence heavily and delegitimize criminal politics ${ }^{57}$; a consequent legislation that frequently, in fact, commercializes the person sacrificing it to the interests of the media system, according to "exclusion" logics of the "dangerous class" contrary to the fundamental guarantees of a social State of law ${ }^{58}$; a legislation, again, that communicates through the information media in the attempt to chase the public opinion, throwing together rules of a system increasingly irrational, disproportionate, chaotic and, therefore, in contrast with the need of extrema ratio of the crime law.

\section{A Preferred Political-Criminal Bildung and the Role of the Criminal Law Culture}

Since, on the one hand, it is undeniable that in the democratic model the control of the institutions cannot be the prerogative of a knowledgeable elite apart from its people representativeness, but it should be extended in some way - even if indirectly - to all the citizens; on the other hand, it is similarly evident that the citizens, so that the institutions have greater opportunities to operate correctly, should have apolitical competence, understood like the awareness of the "public good" and the political lato sensu questions ${ }^{59}$. This awareness, as it is known, can be obtained through the educational agencies, in which a very important role is carried out by the communication media and by the Internet in particular nowadays ${ }^{60}$.

It is hardly questionable, therefore, that the democratic processes operate more adequately only if there are the minimum levels of knowledge for the majority of voters. These standards-increasingly hard to reach when the difficulty level of the public questions increases little by little-are not quantitative, but more importantly qualitative. A superior knowledge of the citizens, therefore, is not connected per se to superior information. Actually, as for the new media, the access to information, de facto, impedes the formation of an adequate knowledge of the phenomenon. The cluster of many news pieces, aside from their possible manipulation, renders the citizens saturated with information, but deprived of knowledge, accustomed, distracted, and unable to exercise the true

\footnotetext{
${ }^{53}$ For all, Fiandaca, 2007: p. 1251; De Vero, 2012: p. 243.

${ }^{54}$ According to Ceri, 2001: p. 98, more than a transfer of power to the citizens, it is a concealment of the same, as—also excluding the use of tested distortion, psychological and statistics technics-, the transfer is deceptive because the participation is subject to manipulation and no responsibilities, and in general the answers are reactions to emotional events when they are not mere effects of "dragging".

${ }^{55}$ Artusi \& Maurizzi, 2010: p. 75, is about internet as an instrument of public participation to a movement or political idea through marketing techniques.

${ }^{56}$ Rangeri, 2001: p. 116; Pittèri, 2007; Ceri, 2001: p. 98.

${ }^{57}$ About the implications of democratic nature of the media system over that one of the criminal system, see the fundamental observations by Palazzo, 2009: p. 200.

${ }^{58}$ Paliero, 2006: pp. 536-537.

${ }^{59}$ About these topics see Dahl, 1992: p. 45, now in Dahl, 2001: p. 134, who defines also the concept of public good, according to a classic (general good) and a more actual and coherent vision through the modern individualism (aggregation of the individual interests).

${ }^{60}$ Education consists mainly in the transmission through communication”, cfr. Dewey, 2000: p. 12.
} 
sense of critique ${ }^{61}$.

The verification of the shortcomings and perversions of the criminal-media system does not mean exemption from promulgating the need of an effort towards the progression of this system and suggesting possible modalities. A sort of Bildung or paideia political-crime would be preferred, adequate to the postmodern democratic and mass media necessity, attempting, ambitiously, to track the ontological content of the minimum levels of knowledge of the citizens, as internalization of those fundamental values constituting the ethos of the civil society. This knowledge could be spread, into the limits of compatibility, also using the mass communication ${ }^{62}$. Naturally, not in the sense of "state pedagogy" through compulsory control instruments of mass media, but in the sense of Bildung as "contact with the culture", as "human education", objectification of freedom through a continuous process that obligates humankind to affirm its own nature, essentially in social and political realms. Therefore, a continuous education of humankind that increasingly approaches faces the culture, does not have a passive attitude, but instead the intention to face the problems, developing intelligence through doubt ${ }^{63}$.

The necessity of this sort of political-criminal Bildung is especially perceived and proved that, currently, the majority of the associated does not come into contact with the criminal law and criminological culture, however, through the mass media, it comes into contact exclusively with the simplistic and "commercialized" described versions of the criminal phenomenon. The model which takes inspiration from this political-criminal paideia should be pursuant to the principles of legitimate criminal politics of a social State of law, directed toward an "inclusive" logic that endorses guarantees and rights, and not "exclusive", which instead currently seem to quantify the media representation of the criminal phenomenon ${ }^{64}$. A model, in other words, of an "open society" in which "freedom of people, non-violence, protection of minorities, defeat of the weak are important values"

As it is not possible to imagine omniscient citizens, this Bildung clearly could not push itself toward more complicated and refined concepts, but at the most it should maintain itself, through simplistic communication methods, on the importance level of legitimate criminal politics principles that constitute the main structure of the occidental modern criminal law systems. The purpose, therefore, should be to give the citizens the minimum cultural instruments to permit a conscious reading of the criminal phenomenon, to know the essential requirements of legitimacy of the legislative choices of penalization, and to permit a basic critical analysis of the judicial tendencies. This process would need a long time, so that these principles and virtues are progressed, "digested", internalized by the citizens until the reduction of the most emotive, irrational and repressive pushes that currently characterize the crime-media system.

This idea might appear naïvely utopic, unattainable if compared to the concreteness of reality. However, this conclusion perhaps darkens the capacity, the collective intelligence if put in "contact with the culture", something that currently does not happen. After all, until the legitimate democratic politics principles are not internalized in the ethos of society, de facto the democratic mechanisms will not function properly and the conflicts will remain more or less latent in the public opinion, mass media, politics, magistracy and science.

The acquisition of this political-criminal ethos, after all, is proof that it encounters difficult obstacles to overcome. In primis within the media system, inasmuch as it is evident that a Bildung rebelling against principles and values does not have the seductive capacity of that information that stimulates more directly the emotions of the audience. This implies that the mass media should abandon, at least in part, the agenda setting concentrated exclusively on the commercialization of information, in order to spread itself, through information operators equipped with adequate cultural instruments, to read the criminal phenomenon more critically and less sensationally.

The obstacles of the political system, instead, are connected to the "commercialization" of choices. Politics, instead, should express itself in an effective and high-cultured debate adopting some decisions, sometimes unpopular at first blush, but inspired by basic ideological/value options able to carry out a pedagogic role. In this, the political world should open mainly to the criminal culture, accepting at least those results reinforced by decades of unequivocal research ${ }^{66}$.

\footnotetext{
${ }^{61}$ Giostra, 2007: p. 64.

${ }^{62}$ About the educational dimension of media, recently see Aroldi, 2012: p. 101.

${ }^{63}$ For a complete analysis of the Bildung concept and its re-elaborated versions, see Cambi, 1994: p. 63.

${ }^{64}$ Paliero, 2006: pp. 536-537.

${ }^{65}$ Popper, 1989: p. 176.

${ }^{66}$ About the relation between crime and political science, the literature is vast. Within many, see, K. Roxin (1970), trad. it. S. Moccia (1998); Vassalli, 1978: p. 999; Moccia, 1984; Bricola, 1988: p. 3; Palazzo, 1997: p. 693; Donini, 2001: p. 27; more recently, Donini, 2010: p. 1067; Palazzo, 2011: p. 4064.
} 
Among the tasks of the jurist, in fact, alongside the most traditional ones such as the interpretation of rules, the dogmatic abstraction and the systematization, there are also those ones related to the criminal politics and the legislative reform ${ }^{67}$. For this reason, coherently with the freedom of research and opinion, the assignment of the "juridical science is to listen to its own voice, formerly in the planning phase of rules, in order to guide the choices of the legislator, in accordance with the principles of legitimate criminal politics and proper actions of standardization [...] Science may demand attention only through its authority, connected to a strong capacity of communication" ${ }^{68}$.

It is indispensable, therefore, a rational communication between science and the legislator, but even if this objective is achieved, in light of the "commercialized" mechanisms described before that condition the criminalization politics of today, it is plausible that the advantageous authority of the doctrine nevertheless proves to be powerless against the legislative options that are exhausted in what seems like a desire to condition the electorate by the media, apart from the principles of legitimate criminal politics, currently nearly unknown to the "general public" "69. The science, then, apart from the essential channel of communication with the legislator, might also open a less indirect communication with the citizens, with that stratum of society that form the so-called public opinion; communication, at a time almost indispensable, and now, instead, could be facilitated exactly through new technologies such as the Internet.

\section{Conclusion}

The criminal-legal science, starting from the earliest one, should involve more criminal politics, displaying itself as more open to the needs and hopes of the citizens. The doctrine should dismount the "ivory tower". It should abandon the most "aristocratic" attitude that keeps in part, detached, barely interested in the most "popular" implications of criminal politics, undertaking instead an active role of this sort of crime-political Bildung through the media ${ }^{70}$. After all, the possibility to firmly carry out this leading role in the collective process of "contact with the criminal law culture", is tied to a more unitary force of the doctrine, at least about the cardinal questions, that is, the principles of a legitimate criminal law. In the absence of a harmonious scientific message, on one hand, there would be the creation of the pretext of politics to divert the reforms; on the other hand, the conflicting message would be deceptive and unable to stabilize that common ethos which is proposed.

The imaginable unattainability of the presumed criminal-political Bildung might be proved only after having seriously certified its practical failure. Before then, before having adopted concrete and long-lasting actions in that sense, even if with all the difficulties involved, it seems to be an instrument on which it is craved the desire to attempt to reduce the symbolic and emergency nature that the criminal system currently presents. The efforts aimed at the social internalization of the principles to establish a legitimate criminal politics, probably do not solve the entire critical scope of the crime system, but most likely do not aggravate it. Every "contact with the culture", also by the media, not commercialized, not simplistic, might only benefit the community; otherwise the necessity would be to completely distrust the discernment capacities of the citizens, which is to say to deny the very bases of every democratic model.

\footnotetext{
${ }^{67}$ See Moccia, 2013: p. 415, that, within other things, has highlighted a solid interaction between crime and dogmatic politics, in such a manner that the function of the crime science is legitimately directed to criminal politics and legislation, too. The mere technical dogmatism, according to the Author, in the end supports the illiberal choices when unblocks theoretical defenses intended to exclude the criminal political problems of the crime system theory. For the necessity of a crime system construction that assumes as principles of reference the criminal politics virtues with a liberal-solidaristic derivation, frequently with norms at the base in Constitutions oriented to principles of the social State of law, see the fundamental work written by Roxin, 1970: p. 37.

${ }^{68}$ Cfr. again Moccia, 2013: pp. 417, 419.

${ }^{69}$ The words of the recent Discorso del Santo Padre Francesco alla delegazione dell'Associazione internazionale di diritto penale, in Bollettino Sala stampa della Santa Sede n. B0787, held at Sala dei Papi on October 23 $3^{\text {rd }}, 2014$ are emblematic: "There is the risk to preserve not even the proportionality of the punishments, which historically reflects the values scale protected by the State. The conception of the penal law as last ratio became weak, as last recourse to the punishment, limited to the serious facts against individual and collective interests more worthy of protection. The debate about the substitution of the prison for other alternative penal sanctions also became weak. In this context, the mission of the jurists is to limit and contain some politicians without any hesitations and the impulse to revenge present in the society, under the pressure of the mass communication media" (Francesco I, 2014).

${ }^{70}$ About this topic see Donini (2006), that is about a permanent task of crime science to control critically the irrational excesses of "penal democracy", that should be carried out also in the mass media, because in other levels the subject remains specialized, without any influence on the public opinion. Recently, about the general debate over the role of the doctrine in the education and legitimation of crime law, see González Cussac, 2013: p. 363; Manna, 2013: p. 389; Moccia, 2013: p. 409.
} 


\section{References}

Amendola, G. (1995). Qualità della vita, bene comune, rischio accettabile: I topoi retorici e/o le strettoie concettuali della valutazione d'impatto ambientale. In F. Beato (Ed.), La valutazione dell'impatto ambientale. Un approccio integrato. Milan.

Arcuri, L. (2004). Ruolo dei mezzi di comunicazione di massa nell’organizzazione delle rappresentazioni sociali e del giudizio delle persone (analisi dei processi attraverso cui i prodotti mediatici possono influenzare la decisione). The Report of the Meeting "Magistrates and Mass Media”, Rome: CSM.

Aroldi, P. (2012). La responsabilità difficile. Media e discernimento. Soveria Mannelli.

Artusi, M., \& Maurizzi A. (2010). Le nuove frontiere del marketing politico. Internet come strumento di costruzione e gestione del consenso. Mercati e Competitività, 75.

Baratta, A. (2000). Diritto alla sicurezza o sicurezza dei diritti. Democrazia e Diritto, 19.

Beck, U. (2000). La società del rischio. Verso una seconda modernità. Rome.

Bentivegna, S. (2002). Mediare la realtà. Mass media, sistema politico e opinione pubblica. Milan.

Benton, M., \& Frazier, P.J. (2002). La funzione di agenda-setting dei mass media ai tre livelli di “complessità” dell'informazione. In S. Bentivegna (Ed.), Mediare la realtà. Mass media, sistema politico e opinione pubblica. Milan.

Bernabè, M., Marcolini, S., \& Rostello, A. (2013). Democrazia nunciativa. Un sistema solido per società liquide, Rome.

Bianchetti, R. (2012). Mass media, insicurezza sociale e recenti orientamenti di politica penale, Milan.

Bricola, F. (1988). Rapporti tra dogmatica e politica criminale. Rivista italiana di Diritto e Procedura Penale, 3.

Burke, E. (1983). No al mandato imperativo. In D. Fisichella (Ed.), La rappresentanza politica. Milan.

Butler, P., \& Collins, N. (2004). Il marketing politico tra prodotto e processo. In A. Mellone, \& B. I. Newman (Eds.), L'Apparenza e l'Appartenenza. Teorie del marketing politico (p. 98).

Calvanese, E. (2011). Media e immigrazione tra stereotipi e pregiudizi. La rappresentazione dello straniero nel racconto giornalistico. Milan.

Cambi, F. (1994). I grandi modelli della formazione. In: F. Cambi, \& E. Frauenfelder (Eds.), La formazione. Studi di pedagogia critica. Milan.

Canestrari, R. (1995). Reazioni psicologiche differenziali e spettacolarizzazione del processo. In F. Galgano (Ed.), Quaderni dell'avvocatura. Padova.

Caniglia, E. (2000). Berlusoni, Perot e Collor come political outsider. Media, marketing e sondaggi nella costruzione del consenso politico. Soveria Mannelli.

Cattaneo, A., \& Zanetto P. (2001). (E)lezioni di successo. Milan.

Cavaliere, A. (2009). Può la "sicurezza” costituire un bene giuridico o una funzione del diritto penale? In W. Hassemer, E. Kempf, \& S. Moccia (Eds.), In dubio pro libertate. Festschrift für Klaus Volk zum 65. Geburtstag (p. 111). München.

Ceretti, A., \& Cornelli, R. (2013). Oltre la paura. Cinque riflessioni su criminalità, società e politica. Milan.

Ceri, P. (2001). Promesse e realtà della teledemocrazia. In P. Fantozzi (Ed.), Politica, istituzioni e sviluppo (p. 98). Soveria Mannelli.

Chomsky, N., \& Herman, E. S. (2014). La fabbrica del consenso. La politica e i mass media. (1998). Trad. it. Rini, S., Milan.

Corchia, L. (2011). La democrazia nell'era d internet. Per una politica dell'intelligenza collettiva. Florence.

Cornelli, R. (2008) Paura e ordine nella modernità. Milan.

Costantini, E., \& Kin, J. (1981). The Partial Juror: Correlates and Causes of Prejudgment. Law \& Society Review, 15, 9-40.

Dahl, R. A. (1992). The Problem of Civic Competence. Journal of Democracy, 3, 45-59.

Dahl, R. A. (2001). Politica e virtù. La teoria democratica nel nuovo secolo. Revision by Fabbrini, S., Rome and Bari.

Davis, R. (1999). The Web of Politics: The Internets Impact on the American Political System.

De Rosa, R. (2014). Cittadini digitali. L'agire politico al tempo dei social media. Santarcangelo di Romagna.

De Vero, G. (2012). Corso di diritto penale. Turin.

Dewey, J. (2000). Democrazia e educazione (1916). Florence.

Dino, A. (2006). I media e i “nemici” della democrazia. Questione Giustizia, 824.

Ditton, J., \& Duffy, J. (1983). Bias in the Newspaper Reporting of Crime News. The British Journal of Criminology, 23, 159-165. 
Donini, M. (2001). Metodo democratico e metodo scientifico nel rapporto fra diritto penale e politica. Rivista italiana di diritto e procedura penale, 27.

Donini, M. (2004). Il volto attuale dell'illecito penale. Milan.

Donini, M. (2006). Il diritto penale di fronte al "nemico". Cassazione Penale, 735.

Donini, M. (2008). Sicurezza e diritto penale. Cassazione Penale, 3558.

Donini, M. (2010). Democrazia e scienza penale nell’Italia di oggi: Un rapporto possibile? Rivista italiana di diritto e procedura penale, 1067.

Eco, U. (2012). Costruire il nemico e altri scritti occasionali. Milan.

Erickson, R. V. (1991). Mass Media, Crime, Law, and Justice. An Institutional Approach. The British Journal of Criminology, 31, 219-249.

Ericson, R., Baranek, P., \& Chan, J. (1989). Negotiating Control. A Study of News Sources. Toronto.

Fiandaca, G. (2007). Legalità penale e democrazia. Quaderni Fiorentini, 1251.

Fiandaca, G. (2013). Populismo politico e populismo giudiziario. Criminalia, 95.

Floridia, A., \& Vignati, R. (2013) Deliberativa, diretta o partecipativa: Quale democrazia per il Movimento 5 stelle? The Annual Convention of the Italian Society of Political Science.

Fornaro, F. (2012). Un non-partito: Il Movimento 5 stelle. Il Mulino, 253.

Forti, G., \& Bertolino, M. (2005) La televisione del crimine. Milan.

Forti, G., \& Redaelli, R. (2005). La rappresentazione televisiva del crimine: La ricerca criminologica. In G. Forti, \& M. Bertolino (Eds.), La televisione del crimine. Milan.

Francesco I (2014) Discorso del Santo Padre Francesco alla delegazione dell’Associazione internazionale di diritto penale. Bollettino Sala stampa della Santa Sede no. B0787.

Franklin, B. (2004). Packaging Politics. Political Communications. Britain’s Media Democrac.

Fuentes Osorio, J. L. (2005). Los medios de comunicación y el derecho penal. In Revista electrónica de ciencia Penal y criminología (p. 16).

Garland, D. (2004). La cultura del controllo. Crimine e ordine sociale nel mondo contemporaneo. Milan.

Gebotys, R. J., Roberts, J. V., \& DasGupta, B. (1988). News Media Use and Public Perceptions of Crime Seriousness. Canadian Journal of Criminology and Criminal Justice, 30, 3.

Giostra, G. (2007). Processo penale e mass media. Criminalia, 66.

Girelli, F. (2007). Insindacabilità parlamentare e divieto di mandato imperativo. Turin.

González Cussac, J. L. (2013). Gli orizzonti, vecchi e nuovi, della dogmatica. Criminalia, 363.

Grandi, R., Pavarini, M., \& Simondi, M. (1985) I segni di Caino: L’immagine della devianza nella comunicazione di massa. Naples.

Gunz, J. (1980). Kriminalberichterstattung in unseren Tageszeitungen Vergeltung oder Vorbeugung: Eine inhaltsanalytische Dokumentation. Linz.

Harrop, M. (1990). Political Marketing. Parliamentary Affairs, 277.

Hassemer, W. (2008). Sicurezza mediante il diritto penale. Critica del diritto, 15.

Iyengar, S., \& Kinder, D. (2002). L’effetto di agenda-setting. In S. Bentivegna (Ed.), Mediare la realtà. Mass media, sistema politico e opinione pubblica. Milan.

Jamieson, K. H. (1991). Dirty Politics: Deception, Distraction, and Democracy. New York, Oxford.

Kirchheimer, O. (1996). The Transformation of the Western European Party System. In J. La Palombara, \& M. Weiner (Eds.), Political Parties and Political Development (p. 177). Princeton. Ora in Sivini G. (1971). Sociologia dei partiti politici, Bologna.

Kury, H. (2005). Mass media e criminalità: L’esperienza tedesca. In G. Forti, \& M. Bertolino (Eds.), La televisione del crimine (p. 319). Milan.

Lévy, P. (2002). L’intelligenza collettiva. Per un'antropologia del cyberspazio. Trad. it. di Feroldi, D., \& Colò, M., Milan.

Lévy, P. (2008). Cyberdemocrazia. Saggio di filosofia politica. Edited by Bianco, G., Milan.

Lombardini, S. (2001). Accelerare non è fare. In J. Acobelli (Ed.), Politica e Internet (p. 62). Soveria Mannelli.

Longo, G. O. (2001). Un rapporto problematico. In J. Acobelli (Ed.), Politica e Internet (p. 70). Soveria Mannelli.

Luhmann, N. (1990). La differenziazione del diritto. Contributi alla sociologia e alla teoria del diritto. Trad. it. di De Giorgi, R., \& Silbernagl, M., Bologna.

Luhmann, N. (1995). Die Realität der Massenmedien. Opladen. http://dx.doi.org/10.1007/978-3-663-16287-2 
Manna, A. (2013). La dottrina tra legislazione e giurisprudenza nel sistema penale. Criminalia, 389.

Marini, R. (2011). Mass media e discussione pubblica. Le teorie dell'agenda setting. Rome and Bari.

Mazzoleni, G. (2001). Una rivoluzione "simbolica”. In J. Acobelli (Ed.), Politica e internet (p. 80). Soveria Mannelli.

Mc Combs, M., \& Shaw, D. (2002). La funzione di agenda-setting dei mass media. In S. Bentivegna (Ed.), Mediare la realtà. Mass media, sistema politico e opinione pubblica. Milan.

Merzagora Betsos, I., \& Travaini, G. V. (2003). Criminalità e paura: Una relazione complessa. Difesa Sociale, 51.

Meyrowitz, J. (2002). Oltre il senso del luogo. Come i media elettronici influenzano il comportamento sociale. Trad. it. Gabi, N., Bologna.

Moccia, S. (1984). Politica criminale e riforma del sistema penale: L’Alternativ-Entwurf e l'esempio della Repubblica federale tedesca. Naples.

Moccia, S. (1997). La perenne emergenza: Tendenze autoritarie nel sistema penale. Naples.

Moccia, S. (2013). L’odierna funzione di “controllo” e “orientamento” della dottrina. Criminalia, 410.

Mori, L. (2011). Il marketing politico e il consenso in democrazia. Iride, 563.

Mori, L. (2012). Procedure democratiche, legittimazione e consenso nell'età del marketing politico: Considerazioni filosofico-politiche. Diritto e questioni pubbliche, 711.

O’Connell, M. (1999). Is Irish Public Opinion towards Crime Distorted by Media Bias? European Journal of Communication, 19, 191-212.

O’Shaughnessy, N. (2004). Il marketing del marketing politico: Un ossimoro? In A. Mellone, \& B. I. Newman (Eds.), L’apparenza e l'appartenenza. Teorie del marketing politico (p. 232). Soveria Mannelli.

Pace, A. (2003). Problematica delle libertà costituzionali. Parte generale: Introduzione allo studio dei diritti costituzionali. Padua.

Padovani, T. (2008). Informazione e giustizia penale: Dolenti note. Diritto penale e processo, 690.

Palazzo, F. (1997). Scienza penale e produzione legislativa: Paradossi e contraddizioni di un rapporto problematico. Rivista italiana di diritto e procedura penale, 693.

Palazzo, F. (2009). Mezzi di comunicazione e giustizia penale. Politica del diritto, 202.

Palazzo, F. (2011). “Requiem” per il codice penale? (Scienza penale e politica dinanzi alla ricodificazione). Cassazione penale, 4064.

Paliero, C. A. (1992). Consenso sociale e diritto penale. Rivista italiana di diritto e procedura penale, 849.

Paliero, C. A. (2006). La maschera e il volto. Percezione sociale del crimine ed "effetti penali” dei media. Rivista italiana di diritto e procedura penale, 493.

Perini, C. (2010). Il concetto di rischio nel diritto penale moderno. Milan.

Pittèri, D. (2007). Democrazia elettronica. Rome.

Popkin, S., \& Dimock M. (1996) La conoscenza dei cittadini, le scorciatoie informative ed il ragionamento politico. In S. Bentivegna (Ed.), Comunicare politica nel sistema dei media (p. 182). Genoa.

Popper, K. (1989). Il futuro è aperto. Milan.

Priulla, G. (2005). Raccontar guai. Che cosa ci minaccia. Che cosa ci preoccupa. Soveria Mannelli.

Pulitanò, D. (2009). Sicurezza e diritto penale. Rivista italiana di diritto e procedura penale, 547.

Pulitanò, D. (2013). Populismi e penale. Sulla attuale situazione spirituale della giustizia penale. Criminalia, 123.

Putini, A. (2013). Al di là di Internet: Fra recupero e dissoluzione della democrazia. Sociologia, 42.

Qualter, T. H. (1985). Opinion Control in the Democracies. London. 138 p.

Rangeri, N. (2001). Il rischio della democrazia diretta. In J. Acobelli (Ed.), Politica e internet (p. 116). Soveria Mannelli.

Robert, R., Livingstone, S., \& Allen, J. (2001). Casino Culture: Media and Crime in a Winner-Loser Society. In K. Stenson, \& R. Sullivan (Eds.), Crime, Risk and Justice: The Politics of Crime Control in Liberal Democracies (p. 174). Cullompton.

Robin, C. (2005). Paura: La politica del dominio. Milan.

Rodotà, S. (1997). Tecnopolitica: La democrazia e le nuove tecnologie della comunicazione. Rome and Bari.

Romano, M. (1985). Legislazione penale e consenso sociale. Jus, 413.

Roxin, C. (1970). Kriminalpolitik und Strafrechtssystem. Berlin. Trad. it. Moccia, S. (1998). Politica criminale e sistema del diritto penale. Naples.

Rumiati, R. (2004). L’influenza mediatica sulla decisione. The Report of the Meeting "Magistrates and Mass Media”. Rome: 
Organized by CSM.

Savadori, L., \& Ruminati, R. (2005). Nuovi rischi, vecchie paure. Bologna.44 p.

Scammel, M. (2004). Cosa insegna il marketing alla scienza politica. In A. Mellone, \& B. I. Newman (Eds.), L’Apparenza e l'Appartenenza. Teorie del marketing politico (p. 39).

Scammell, M. (1995). Designer Politics: How Elections Are Won. London.

Scarciglia, R. (2005). Il divieto di mandato imperativo. Contributo a uno studio di diritto comparato. Padua.

Schiaffo, F. (2012). La creazione della insicurezza in Italia e negli USA: Gli esiti istituzionali tra effetti simbolici e disastri reali. Critica del diritto, 52.

Schneider, H. J. (1995). La criminalité et sa représentation par les mass media. Revue internationale de criminologie et de police technique, 48, 148.

Shapiro, A. L. (1999). The Control Revolution: How the Internet Is Putting Individuals. In Charge and Changing the World We Know. New York.

Simon, J. (2008). Il governo della paura. Guerra alla criminalità e democrazia in America. Milan.

Slovic, P. (2000). The Perception of Risk. London.

Smith, G., \& Saunders, J. (1990). The Application of Marketing to British Politics. Journal of Marketing Management, 5 , 295-306.

Stella, F. (2001). Giustizia e modernità. La protezione dell'innocente e la tutela delle vittime. Milan. 387 p.

Studebaker, C. A., \& Penrod, S. D. (1997). Pretrial Publicity: The Media, the Law, and Common Sense. Psychology, Public Policy, and Law, 3, 428-460.

Surette, R. (2007). Media, Crime, and Criminal Justice: Images, Realities, and Policies. Belmont.

Travaini, G. V. (2002). Paura e criminalità. Dalla conoscenza all'intervento. Milan.

Tursi, A., \& de Kerckhove, D. (2006) Dopo la democrazia? Il potere e la sfera pubblica nell'epoca delle reti. Milan.

Tyler, T. R. (2006). Viewing CSI and the Threshold of Guilt: Managing Truth and Justice in Reality and Fiction. The Yale Law Journal, 115, 1050-1085.

Vassalli, G. (1978). Politica criminale e sistema penale, ne Il Tommaso Natale. Scritti in memoria di Girolamo Bellavista, 2, 999.

Vianello, F., \& Padovan, D. (1999). Criminalità e paura: La costruzione sociale dell'insicurezza. Dei delitti e delle pene, 247.

Wring, D. (2004). Le teorie del marketing politico. In A. Mellone, \& B. I. Newman (Eds.), L'Apparenza e l'Appartenenza. Teorie del marketing politico (p. 121).

Zaffaroni, E. R. (1989). En busca de las penas perdidas. Delegitimacion y dogmatica juridico-penal. Bueons Aires. Trad. it. di Seminara, G., Revision by Cavaliere, A. (1994). Alla ricerca delle pene perdute. Delegittimazione e dommatica giuridico-penale. Naples. 139 p.

Zanon, N. (1991). Il libero mandato parlamentare. Saggio critico sull'articolo 67 della Costituzione. Milan. 